\title{
Peran Kepolisian Resort Kediri dalam penanggulangan tindak pidana perjudian
}

\author{
The role of Kediri Regional Police in countering gambling crime \\ Muhammad Aldy Sulaiman \\ Polda Jawa Timur \\ Surabaya, 60231, Jawa Timur, Indonesia \\ E-mail of corresponding author: m.aldy.sulaiman@pasca.unair.ac.id
}

\begin{abstract}
Abstrak
Pada dasarnya para pelaku perjudian sudah banyak yang diseret ke depan pengadilan untuk mempertanggung jawabkan perbuatannya. Namun dalam praktiknya pelaku perjudian tidak menyadari dan tetap mengulangi lagi perbuatannya bahkan dilakukan secara terbuka dan lebih berani. Tujuan penelitian ini adalah untuk mengetahui peran kepolisian resort Kediri dalam penanggulangan tindak pidana perjudian. Metode yang digunakan penelitian ini menggunakan metode pendekatan kualitatif, yaitu suatu tata cara penelitian yang menghasilkan data diskriptif-analitis Hasil penelitian membuktikan peran Polres Kediri dalam mengatasi tindak pidana dengan upaya non-pidana dan pidana. Faktor-faktor yang menjadi penghambat dan pendorong dalam penanggulangan yang ikut serta dalam perjudian, demi masyarakat, adalah faktor penghambat yang terdiri dari kontrol sosial yang kurang maksimal, faktor ekonomi, tingkat masyarakat yang rendah, respons yang rendah dari masyarakat terhadap sosialisasi atau penyuluhan yang dilakukan oleh polisi, penegak hukum kurang bertanya dalam bertindak. Sementara itu, faktor penggeraknya adalah anggota Bhabinkamtibmas yang terus meningkatkan kemampuan mereka, jaminan keamanan oleh petugas perlindungan masyarakat sehingga suasana tertib dan nyaman tetap terjaga, pengembangan potensi yang ada di masyarakat lingkungan setempat agar menjadi kekuatan untuk memelihara situasi aman dan mencegah gangguan yang meresahkan masyarakat.
\end{abstract}

Kata kunci: perjudian; kesadaran; pengadilan; pidana; polisi

\begin{abstract}
Many gambling crime perpetrators have been brought before the court to take responsibility for their actions. However, those gambling crime perpetrators never seem to realize that it is wrong and keep doing it. They even get more daring and gamble openly. This study aims to investigate the role of Kediri Regional Police in countering such gambling crime. The study was done with qualitative methods to work with and produce descriptive-analytical data and results. The results prove that the role of Kediri Regional Police in countering criminal acts is executed in penal and non-penal efforts. Furthermore, the study also identifies several inhibiting and driving factors in counter measuring crime of gambling for the betterment of the society. The inhibiting factors are weak social control, economic factors, low education, community's low response towards promotion and counseling conducted by the police, and police officers taking measures without confirming. On the other hand, the driving factors are members of the Bhabinkamtibmas (members of the Indonesian National Police who are tasked with fostering public order and security) continuing improving their skills, security insurance given by these officers maintaining ordered and contented situation, and improvement in the community's potential to generate strength to maintain secured situation and prevent disturbance to the society.
\end{abstract}

Keywords: gambling; awareness; court; criminal; police

\section{Pendahuluan}

Di Kota Kediri, perjudian seakan-akan merupakan suatu hal yang biasa dilakukan, hampir di setiap sudut kota baik siang maupun malam orang bisa menjumpai masyarakat yang melakukan perjudian (Wahyudi 2015). Seharusnya masyarakat malu dengan penyakit sosial yang penyebabnya sangat kompleks dan bersifat multidimensional ini, apalagi bila harus menelaah akibatnya yang demikian destruktif dan merusak. Banyaknya kasus perjudian yang beraneka ragam di Indonesia pada umumnya dan di wilayah Kediri pada khususnya sangat membahayakan bagi kelangsungan aktivitas perekonomian dan dapat mengarah pada peningkatan dilakukannya tindak pidana lain di masyarakat. Berbagai model perjudian yang ada seperti: Cap Jie Kia, Togel (Toto Gelap), Dadu Kopyok, Lotre, 
Remi, Poker, Sam Gong, Kiu-kiu, dan lain-lain kelihatannya semakin marak di masyarakat (Adam 2007; Sallaz 2008; Septanto 2019). Pengaruh permainan ini dapat menimbulkan penilaian yang tidak baik dari orang terhadap perbuatan-perbuatan tidak baik lainnya karena orang sering melihat adanya hubungan antara perjudian, penyalahgunaan minuman keras, dan pelacuran (Collins 2003). Jenis-jenis perjudian itu sering kali dilakukan di tempat-tempat umum seperti terminal, pasar, pinggir jalan raya, dan tempat-tempat keramaian lainnya. Ada sebagian warga masyarakat Kediri apabila mempunyai hajatan atau syukuran diselenggarakan dengan menanggap kesenian pada malam harinya, dalam keramaian inilah sering kali datang bandar-bandar judi, diantaranya bandar togel, bandar lotre, dan lain sebagainya. Namun jika tidak ada keseniannya biasanya perjudian itu dilakukan di dalam rumah orang yang mempunyai hajatan tersebut. Alat permainan judinya pun hanya sekedar kartu remi, kartu keplek, domino, atau kartu cap jie kia.

Pada dasarnnya para pelaku perjudian sudah banyak yang diseret ke depan Pengadilan untuk mempertanggungjawabkan perbuatannya. Namun dalam prakteknya pelaku perjudian tidak menyadari dan tetap mengulangi lagi perbuatannya bahkan dilakukan secara terbuka dan lebih berani (Light 1977; Fine 1992). Dengan melihat perjudian yang ada di masyarakat dan dengan maraknya tindak pidana perjudian, penulis mencoba mengkaji mengenai kebijakan yang dilakukan polisi dan kendala yang dihadapi dalam penertiban tindak pidana perjudian. Aparat kepolisian bertugas untuk menegakkan ketertiban dan menjaga ketenteraman dalam masyarakat, salah satunya dengan cara menertibkan judi yang merupakan perbuatan yang nyatanyata telah melanggar peraturan hukum (Crouch 2009). Dalam hal ini masyarakat di harapkan mau berperan serta mendukung aparat penegak hukum agar penegakan hukum dapat terlaksana. Fenomena perjudian yang terjadi di wilayah hukum Kabupaten Kediri menjadi perhatian serius pihak Kepolisian Resort Kediri. Berbagai upaya pencegahan telah dilakukan agar perjudian tidak meresahkan warga masyarakat. Dalam penanganan masalah perjudian tersebut tentunya ada kebijakan-kebijakan yang dikeluarkan oleh Kepolisian Resort Kediri.

Perjudian adalah pertaruhan dengan sengaja yaitu mempertaruhkan satu nilai atau sesuatu yang dianggap bernilai, dengan menyadari adanya resiko dan harapan-harapan tertentu pada peristiwaperistiwa permainan, pertandingan, perlombaan dan kejadian-kejadian yang belum pasti hasilnya (Schissel 2001; Fulton 2015). Dalam arti kata luas yang termasuk permainan judi juga segala permainan yang umumnya kemungkinan untuk menang tergantung pada secara kebetulan atau nasib, biarpun kemungkinan untuk menang itu bisa bertambah besar pula karena latihan atau kepandaian pemain. Selain dari pada itu termasuk permainan judi juga segala pertaruhan dalam pacuan kuda, perlombaan sepak bola, pertaruhan antara orang-orang yang tidak ikut sendiri dalam perlombaan itu, dan sebagainya (Lopez-Gonzalez et al. 2019; Killick \& Griffiths 2019). Fakta sosial menurut Durkheim dalam Stepnisky (2018) terdiri atas dua macam: (1) Dalam bentuk material yaitu barang sesuatu yang dapat disimak ditangkap dan diobservasi. Fakta yang membentuk material ini adalah bagian dari dunia nyata. Contohnya arsitektur dan norma hukum. (2) Dalam bentuk non material yaitu sesuatu yang dianggap nyata (external). Fakta sosial jenis ini merupakan fenomena yang bersifat inter subjective yang hanya dapat muncul dari dalam kesadaran manusia. Contohnya adalah egoisme, altruisme, dan opini.

Sebab timbulnya kejahatan menurut beberapa teori, antara lain: (1) Teori Psikogenesis (Psikogenesis dan Psikatris) teori ini menekankan sebab tingkah laku yang menyimpang dari sesorang dilihat dari aspek psikologis atau kejiwaan antara lain faktor kepribadian, intelegencia, fantasi, konflik batin, emosi dan motifasi seseorang (Corner 2017; Saputra et al. 2018). (2) Teori biologis, teori mengemukakan tentang batasan tentang penyebab terjadinya kejahatan. Tingkah laku menyimpang yang dilakukan seseorang muncul karena faktor-faktor psikologis dan jasmania seseorang. Dalam teori ini muncul ahli yang menyatakan bahwa kecenderungan untuk berbuat jahat, diturunkan oleh keluarga, dalam hal ini orang tua (kejahatan warisan biologis) (Rimland 1969). Inti ajaran ini adalah bahwa sususnan tertentu dari kepribadian seseorang berkembang terpisah dari polapola kebudayaan sipelaku bagaimanapun keadaan lingkungan sosialnya itu. (3) Teori sosiogenesis, teori ini menekankan pada tingkah laku menyimpang dari seseorang menurut aspek sosiologis, misalnya yang dipengaruhi oleh struktur sosial (Wheaton 1978). Faktor sosial dan kultur sangat mendominasi struktur lembaga dan 
peranan sosial terhadap setiap individu ditengah masyarakat, ditengah kelompoknya maupun terhadap dirinya sendiri (Elias 1984).

Konsep perjudian sebagai perilaku menyimpang adalah perilaku dari para warga masyarakat yang dianggap tidak sesuai dengan kebiasaan, tata aturan atau norma sosial yang berlaku (Eadington 1976; Nicoll 2019; Septanto 2019). Tindakan yang menyimpang dilakukan orang-orang tidak selalu berupa tindak kejahatan besar seperti merampok, korupsi, menganiaya, atau membunuh. Melainkan bisa pula cuma berupa tindakantindakan pelanggaran kecil-kecilan, semacam berkelahi dengan teman, suka meludah disembarang tempat berpacaran hingga larut malam, makan dengan tangan kiri dan lain-lain.

Penggolongan perilaku menyimpang menurut Cohen (2018) secara umum antara lain: (1) Tindakan yang mengkonfrim, yaitu perilaku yang tidak sesuai dengan nilai-nilai atau norma-norma yang ada. (2) Tindakan yang anti sosial atau asosiasi yaitu tindakan yang melawan kebiasaan masyarakat atau kepentingan umum. (3) Tindakan-tindakan kriminal, yaitu tindakan yang nyata-nyata telah melanggar aturan-aturan hukum tertulis dan mengancam jiwa atau keselamatan jiwa orang lain.

Sudut pandang perilaku menyimpang perilaku menyimpang dapat didefinisikan secara berbeda berdasarkan sudut pandang. 1) Secara statistikal, segala sesuatu yang bertolak dari suatu tindakan yang bukan rata-rata atau perilaku yang jarang dan tidak sering dilakukan. Pendekatan ini berasumsi bahwa, sebagaian besar masyarakat dianggap melakukan cara-cara dan tindakan yang benar (Tittle \& Dollar 2019). 2) Secara absolute atau mutlak, berangkat dari aturan-aturan sosial yang dianggap sebagai sesuatu yang mutlak atau jelas dan nyata. Semua anggota masyarakat harus menyetujui tentang aturanaturan dasar yang dimana disebut sebagai penyimpangan atau bukan penyimpang, dengan demikian diharapkan setiap orang dapat bertindak sesuai dengan nilai-nilai yang dianggap benar dan menghindari perilaku yang diangap menyimpang (Marshall \& Meier 2018). Contohnya aturan-aturan yang ketat dan nilainilai kepantasan yang ditunjukan pada masyakat pedesaan yang masih memegang teguh adat istiadat serta nilai-nilai tradisional. 3) Secara reaktif, di mana penyimpangan berkenaan dengan reaksi masyarakat atau agen kontrol sosial dan kemudian member cap atau tanda (labeling) terhadap si pelaku, maka perilaku itu telah dicap menyimpang, demikian pula si pelaku juga dikatakan menyimpang (Bernburg 2019). 4) Secara normatif yaitu penyimpangan pelanggaran dari suatau norma sosial, norma dalam hal ini suatau standar tentang apa yang seharusnya dilakukan atau seharusnya tiadak dipikirkan, dikatakan, atau dilakukan oleh warga masyarakat pada suatu keadaan tertentu. Pelanggaran-pelanggaran terhadap norma, seringkali diberi sanksi oleh penonton sosialnya (Inderbitzin et al. 2016). Sanksi- sanksi tersebut merupakan tekanan dari sebagaian besar anggota masyarakat yang merasa konform terhadap norma-norma tersebut.

\section{Metode Penelitian}

Jenis penelitian ini menggunakan metode pendekatan kualitatif, yaitu suatu tata cara penelitian yang menghasilkan data diskriptif-analitis (Silverman 2016). Data diskriptif yaitu apa yang dinyatakan oleh responden secara tertulis atau lisan dan juga perilakunya yang nyata, yang diteliti dan dipelajari sebagai sesuatu yang utuh. Sementara itu, pendekatan penelitian yang digunakan adalah pendekatan kualitatif.

Jenis data yang dikumpulkan terutama merupakan data pokok yaitu data yang paling relevan dengan pokok permasalahan yang diteliti. Namun untuk kelengkapan dan keutuhan dari masalah yang diteliti, maka akan disempurnakan dengan penggunaan data pelengkap yang berguna untuk melengkapi data pokok dan data pelengkap tersebut adalah data primer, yakni wawancara dengan pihak-pihak yang terkait dalam pengambilan kebijakan penanggulangan tindak pidana perjudian di wilayah hukum Kediri antara lain Kasubbag Reskrim, Polisi serta pihak yang terkait, serta data sekunder yang merupakan data yang berasal dari data yang sudah tersedia misalnya, dokumen resmi, surat perjanjian atau buku-buku.

Sumber data primer adalah sumber data yang diperoleh secara langsung dari lapangan yang meliputi keterangan atau data hasil wawancara (King et al. 2018) kepada pejabat yang berwenang dalam hal 
kebijakan penanggulangan tindak pidana perjudian di wilayah hukum Kabupaten Kediri. Sumber data sekunder merupakan sumber data yang didapatkan secara langsung berupa keterangan yang mendukung data primer. Sumber data sekunder merupakan pendapat para ahli, dokumen-dokumen, tulisan-tulisan dalam buku ilmiah, dan literatur.

Teknik pengumpulan data dalam studi lapangan ini penulis melaksanakan kegiatan wawancara, yaitu suatu metode pengumpulan data dengan cara mendapatkan keterangan secara lisan dari seorang responden dengan bercakap-cakap secara langsung. Wawancara ini bertujuan untuk mengumpulkan keterangan tentang kehidupan manusia serta pendapat-pendapat mereka. Secara umum ada dua jenis teknik wawancara, yaitu wawancara terpimpin (terstruktur) dan wawancara dengan teknik bebasa (tidak terstruktur) yang disebut wawancara mendalam (in-depth interviewing). Dalam wawancara ini dilakukan dengan cara mengadakan komunikasi langsung dengan pihak-pihak yang dapat mendukung diperolehnya data yang berkaitan dengan permasalahan yang diteliti guna memperoleh data baik lisan maupun tulisan atas sejumlah data yang diperlukan.

Teknik analisis data dalam operasionalisasinya, peneliti membatasi permasalahan yang diteliti dan juga membatasi pada pertanyaan-pertanyaan pokok yang perlu dijawab dalam penelitian. Dari hasil penelitian tersebut data yang sudah diperoleh disusun sesuai dengan pokok permasalahan yang diteliti kemudian data tersebut diolah dalam bentuk sajian data.

\section{Hasil dan Pembahasan}

\section{Upaya Polres Kediri dalam penanggulangan tindak pidana perjudian}

Sejumlah kasus tindak pidana perjudian yang ditemukan di wilayah hukum Polres Kediri, dimana jumlah kasus dalam dua tahun terakhir adalah 60 kasus tindak pidana perjudian, yaitu 32 kasus pada tahun 2018, dan 28 kasus pada tahun 2017. Mengenai bentuk upaya yang dapat dilakukan dalam upaya non-penal dan upaya penal, dimana adalah sebagai berikut:

Upaya non penal (preventif): Pertama, melakukan sosialisasi atau penyuluhan kepada masyarakat, penyuluhan hukum ini dilakukan dalam rangka untuk meningkatkan kesadaran hukum masyarakat. Dalam hal ini Polres Kediri, bekerjasama dengan instansi pemerintah setempat seperti lurah atau kepala desa agar mengumpulkan dan mengundang warganya untuk menghadiri penyuluhan hukum yang akan diberikan oleh Polres Kediri. Penyuluhan hukum dalam rangka untuk meningkatkan kesadaran hukum masyarakat, dilakukan bersama dengan lurah atau kepala desa agar mengumpulkan dan mengundang warganya untuk menghadiri penyuluhan hukum yang akan diberikan oleh Polres Kediri. Dalam penyuluhan tersebut anggota polisi memberikan pengetahuan dasar mengenai hukum kepada masyarakat, khususnya mengenai perjudian yang diatur dalam kuhp, apa saja yang diatur beserta sanksinya apa bila hukum itu dilanggar. Dengan demikian, masyarakat akan tahu resiko yang akan diterimahnya apabila tetap melakukan perjudian tersebut, sehinggah dengan resiko tersebut, ia tidak akan mau untuk berjudi. Hal ini berarti penyuluhan hukum itu dapat melahirkan masyarakat yang taat hukum.

Kedua, melakukan operasi dan pengawasan di tempat-tempat keramaian. Untuk mencegah munculnya perjudian maka kegiatan penjagaan terhadap tempat-tempat keramaian yang menjadi tempat rawan terjadinya tindak pidana perjudian seperti warung-warung, pasar, pesta pernikahan, sunatan maupun acara-acara yang di adakan di daerah-daerah yang jauh dari kota. Ketiga, mengadakan patroli dan pengawasan secara rutin dan kontinyu. Patroli dan pengawasan secara rutin dan kontinyu yang dilakukan oleh Polres Kediri yaitu khususnya di tempat tempat yang rawan dilakukannya perjudian seperti warung-warung sehingga masyarakat pun akan menjadi takut untuk melakukan perjudian. Jadi apabila telah dilakukan patroli dan pengawasan secara rutin dan terus menerus, dimana Polres Kediri mengajak kepada warga setempat untuk melapor apabila ditemukan perjudian di wilayahnya.

Keempat, melakukan pengintaian. Untuk mengungkap kasus perjudian anggota kepolisian melakukan pengintaian di daerah, di mana daerah tersebut di duga rawan perjudian dalam melakukan pengintaian 
ini pihak kepolisian bekerja sama dengan tokoh masyarakat, dengan cara ini para pelaku tindak pidana perjudian dengan mudah dapat di tangkap ditempat tanpa ada pelaporan terlebih dahulu dari masyarakat karena polisi sudah mengetahui para pelaku tindak pidana perjudian. Berdasarkan pernyataan tersebut, dapat diartikan bahwa Polres Kediri merangkul tokoh masyarakat untuk melakukan pengintaian terhadap beberapa terduga, sehingga dapat ditemukan bukti yang valid mengenai pelaku perjudian. Hal ini dikarenakan tokoh masyarakat telah mengenal wilayah dan pemerintah daerah setempat, dimana dinilai dapat mempermudah pengintaian tersebut.

Upaya penal (represif): Pertama, melakukan penyelidikan dan mencari informasi. Dalam upaya Kepolisian menanggulangi tindak pidana perjudian, maka Polres Kediri membentuk krimserse dalam setiap anggota menguasai satu wilayah dengan bantuan Polsek setempat, sehingga dapat dengan mudah menentukan daerah yang rawan perjudian, maka krimserse ini dibantu juga bimmas, dibentuk juga satu bimmas dalam satu kelurahan, dengan adanya bimmas ini membentuk informal, menemui tokoh-tokoh masyarakat untuk jangan sampai melakukan perjudian yang hakikatnya itu melanggar aturan perundang-undangan.bekerja sama dengan tokoh tokoh masyarakat dan tokoh- tokoh pemuda untuk mendapatkan informasi. Kedua, ikut bermain judi. Untuk mengungkap kasus perjudian anggota Kepolisian melakukan penyamaran dengan ikut bermain judi. Dengan cara ini para pelaku tindak pidana perjudian dengan mudah dapat di tangkap ditempat tanpa ada pelaporan terlebih dahulu dari masyarakat karena Polisi sudah mengetahui para pelaku tindak pidana perjudian.

Ketiga, melakukan penyamaran. Untuk mengungkap kasus perjudian anggota kepolisian melakukan penyamaranmenjadi masyarakat biasa dan bekerja sama dengan tokoh masyarakat, dengan cara ini para pelaku tindak pidana perjudian dengan mudah dapat di tangkap ditempat tanpa ada pelaporan terlebih dahulu dari masyarakat karena Polisi sudah mengetahui para pelaku tindak pidana perjudian. Kelima, menangkap tersangka dan menyita barang bukti. Polres Kediri dalam melakukan operasi untuk mencegah dan memberantas perjudian, dengan bantuan polsek-polsek setempat yaitu menangkap pelaku dan menyita barang bukti yang di temukan di TKP maupun barang yang diduga menjadi alat untuk berjudi maupun hasil menang judi.

\section{Faktor yang menjadi penghambat dan pendorong dalam penanggulangan tindak pidana perjudian guna menciptakan ketertiban masyarakat}

Faktor penghambat anatara lain: pertama, kontrol sosial masyarakat kurang maksimal. Hal yang menjadi kendala saat ini adalah masyarakat masih menganggap judi kecil adalah biasa, sehingga kurang terdapat kontrol sosial yang sebagaimana mestinya terhadap tindak pidana perjudian. Kedua, faktor ekonomi. Bagi masyarakat dengan status sosial dan ekonomi yang rendah perjudian seringkali dianggap sebagai suatu sarana untuk meningkatkan taraf hidup mereka. Karena mereka berfikir, dengan modal yang sangat kecil mereka akan mendapatkan keuntungan yang sebesar-besarnya atau menjadi kaya dalam sekejab tanpa usaha yang besar. Selain itu kondisi sosial masyarakat yang menerima perilaku berjudi juga berperan besar terhadap tumbuhnya perilaku tersebut dalam komunitas. Ketiga, rendahnya tingkat pendidikan masyarakat. Sangat masuk akal jika faktor rendahnya tingkat pendidikan masyarakat memiliki efek yang besar terhadap perilaku berjudi, terutama menyangkut keinginan untuk terus berjudi. Apa yang pernah dipelajari dan menghasilkan sesuatu yang menyenangkan akan terus tersimpan dalam pikiran seseorang dan sewaktu-waktu ingin diulangi lagi. Sehinga tingkat pendidikan sangat mempengaruhi seseorang untuk melakukan suatu perilaku menyimpang, tidak terkecuali perjudian.

Kempat, kurangnya respon masyarakat terhadap sosialisasi atau penyuluhan yang dilakukan pihak kepolisian. Kendala yang dihadapi pihak kepolisian dalam melakukan sosialisasi atau penyuluhan tentang larangan bermain judi yaitu kurangnya respon masyarakat terhadap apa yang dilakukan pihak kepolisian ini membuktikan bahwa masyarakat masih minim pengetahuan tentang peraturan undangundang yang melarang bermain judi karena masyarakat menganggap bahwa perjudian itu merupakan hiburan semata dan menganggap tidak ada peraturan yang mengikat yang akan diberi sanksi ketika dilanggar. Kelima, penegak hukum kurang tegas dalam bertindak. Sikap pelaksana merupakan faktor yang diharapkan berlangsung efektif guna mengetahui apa yang harus dilakukan dan memiliki 
kapabilitas untuk melaksanakan kebijakan tersebut. Akan tetapi, didapati sifat kurang serius (kecenderungan disposisi) yang ditunjukkan pihak pemda, dan pihak anggota babinsa, yang terkesan masih belum tegas. Untuk mengatasi permasalahan yang terjadi wilayah hukum Polres Kediri perlu ketegasan anggota.

Faktor pendorong antara lain: petama, anggota Bhabinkamtibmas yang terus meningkatkan kemampuan. Bhabinkamtibmas harus memposisikan diri sebagai mitra kerja masyarakat yang menjadi aktualisasi dari tugas polisi di tengah-tengah masyarakat dalam menciptakan keamanan, sesuai dengan dasar pembentukan Bhabinkamtibmas itu sendiri, yaitu untuk membangun kemitraan dengan masyarakat, dengan cara membentuk kesadaran masyarakat akan keamanan dan ketertiban, tidak bisa tergantung pada polisi, tapi juga dilakukan oleh mereka sendiri. Bhabinkamtibmas dibentuk guna melakukan pemantauan potensi gangguan keamanan di desa atau kelurahan, bekerja sama dengan masyarakat untuk menciptakan keamanan dan ketertiban. Kedua, jaminan keamanan oleh petugas perlindungan masyarakat sehingga suasana tertib dan nyaman tetap terjaga. Pertugas perlindungan masyarakat dianggap sebagai aparatur yang diperlukan oleh masyarakat di lingkungan tempat tinggal, sehingga keinginan untuk mewujudkan keamanan, dan ketentraman dapat tercapai. Selain itu bantuan dari aparat linmas (perlindungan masyarakat) dapat pula mendukung dan memberi semangat untuk memberantas tindak pidana perjudian di wilayah hukum Polres Kediri.

Ketiga, pengembangan potensi yang ada di masyarakat lingkungan setempat agar menjadi kekuatan untuk memelihara situasi aman dan mencegah gangguan yang meresahkan masyarakat. Pada setiap usaha pencegahan kejahatan sangat dibutuhkan keterlibatan dan peran serta masyarakat, terkait demikian hal-hal atau kondisi-kondisi yang mendukung dimungkinkannya kegiatan kolektif di dalam masyarakat yang bersangkutan sangat menentukan terselenggaranya usaha pencegahan kejahatan tersebut. Konsep peran serta masyarakat dalam pencegahan dan penanggulangan kejahatan bukan merupakan suatu konsep baru, sebelum didirikannya organisasi polisi yang modern, tugas-tugas pembinaan ketertiban masyarakat merupakan tanggung jawab dari masyarakat itu sendiri.

\section{Simpulan}

Peran Polres Kediri dalam penanggulangan tindak pidana perjudian yaitu melalui upaya non penal dan penal. Upaya non penal dilakukan dengan melakukan sosialisasi atau penyuluhan kepada masyarakat, melakukan operasi dan pengawasan di tempat-tempat keramaian, mengadakan patroli dan pengawasan secara rutin dan kontinyu dan melakukan pengintaian. Sementara itu upaya penal dilakukan dengan Melakukan penyelidikan dan mencari informasi, ikut bermain judi melakukan penyamaran menangkap tersangka dan menyita barang bukti.

Faktor yang menjadi penghambat dan pendorong dalam penanggulangan tindak pidana perjudian guna menciptakan ketertiban masyarakat yaitu faktor penghambat terdiri dari kontrol sosial masyarakat kurang maksimal, faktor ekonomi, rendahnya tingkat pendidikan masyarakat, kurangnya respon masyarakat terhadap sosialisasi atau penyuluhan yang dilakukan pihak kepolisian, penegak hukum kurang tegas dalam bertindak. Sementara, faktor pendorong yaitu anggota Bhabinkamtibmas yang terus meningkatkan kemampuan, jaminan keamanan oleh petugas perlindungan masyarakat sehingga suasana tertib dan nyaman tetap terjaga dan pengembangan potensi yang ada di masyarakat lingkungan setempat agar menjadi kekuatan untuk memelihara situasi aman dan mencegah gangguan yang meresahkan masyarakat.

\section{Daftar Pustaka}

Bernburg JG (2019) Labeling Theory. In Handbook on crime and deviance (pp. 179-196). UK: Springer.

Cohen AK (2018) The Sociology of the Deviant Act: Anomie Theory. In Deviance and Liberty. UK: Routledge.

Collins P (2003) Gambling and the Public Interest. Greenwood Publishing Group. 
Corner EJ (2017) The Psychogenesis of Terrorism (Doctoral dissertation, UCL (University College London).

Crouch M (2009) Religious regulations in Indonesia: Failing vulnerable groups? Review of Indonesian and Malaysian Affairs 43 (2).

Eadington WR (1976) Gambling and Society: Interdisciplinary Studies on the Subject of gambling. Charles C. Thomas.

Elias N (1984) On the sociogenesis of sociology. Amsterdams Sociologisch Tijdschrift 11 (1):14-52.

Fine GA (1992) The depths of deep play-the rhetoric and resources of morally controversial leisure. Play \& Culture 5 (3):246-251.

Fulton C (2015) Playing Social Roulette: The Impact of Gambling on Individuals and Society in Ireland. Theses: University College Dublin.

Inderbitzin M, Bates KA \& Gainey RR (2016) Deviance and Social Control: A Sociological Perspective. UK: Sage Publications.

Killick EA \& Griffiths MD (2019) In-play sports betting: A scoping study. International Journal of Mental Health and Addiction 17 (6):1456-1495.

King N, Horrocks C \& Brooks J (2018) Interviews in Qualitative Research. UK: SAGE Publications Limited.

Light I (1977) Numbers gambling among blacks: A financial institution. American Sociological Review: 892-904.

Lopez-Gonzalez H, Estévez A \& Griffiths MD (2019) Internet-based structural characteristics of sports betting and problem gambling severity: Is there a relationship? International Journal of Mental Health and Addiction 17 (6):1360-1373.

Marshall BC \& Meier RF (2018) Sociology of Deviant Behavior. Cengage Learning.

Nicoll FJ (2019) Gambling in Everyday Life: Spaces, Moments and Products of Enjoyment. UK: Routledge.

Rimland B (1969) Psychogenesis Versus Biogenesis: The Issues and The Evidence. Changing Perspectives in Mental Illness. New York: Holt, Rinehart \& Winston.

Sallaz JJ (2008) Deep plays: A comparative ethnography of gambling contests in two postcolonies. Ethnography 9 (1):5-33.

Saputra TAA \& Soponyono E (2018) Criminology study on pedophilia prevention in Inonesia. Criminology 9 (2): 117-127.

Schissel B (2001) Betting against youth: The effects of socioeconomic marginality on gambling among young people. Youth \& Society 32 (4):473-491.

Septanto A (2019) Perilaku menyimpang masyarakat penjudi merpati di Surabaya. Jurnal Sosiologi Dialektika 14 (2): 126-131.

Silverman D (Ed.) (2016) Qualitative Research. UK: Sage Publication.

Stepnisky J (2018) Types of Sociological Theory. Core Concepts in Sociology, 295.

Tittle CR \& Dollar CB (2019) Control Balance Theory of Deviance. In Handbook on Crime and Deviance (pp. 243-257). Springer, Cham.

Wahyudi T (2015) Hambatan penyidikan terhadap tindak pidana perjudian (Studi di Kepolisian Resort Kediri Kota). Kumpulan Jurnal Mahasiswa Fakultas Hukum.

Wheaton B (1978) The sociogenesis of psychological disorder: Reexamining the causal issues with longitudinal data. American Sociological Review, 383-403. 